\title{
Clumped-isotope palaeothermometry and LA-ICP-MS U-Pb dating of lava-pile hydrothermal calcite veins
}

\author{
J. M. MacDonald ${ }^{1}$ (1) J. W. Faithfull ${ }^{2}$. N. M. W. Roberts ${ }^{3} \cdot$ A. J. Davies ${ }^{4} \cdot$ C. M. Holdsworth ${ }^{1}$ M. Newton ${ }^{1}$. \\ S. Williamson ${ }^{1}$ - A. Boyce ${ }^{5}$. C. M. John ${ }^{4}$
}

Received: 15 February 2019 / Accepted: 1 July 2019 / Published online: 11 July 2019

(c) The Author(s) 2019

\begin{abstract}
Calcite veins are a common product of hydrothermal fluid circulation. Clumped-isotope palaeothermometry is a promising technique for fingerprinting the temperature of hydrothermal fluids, but clumped-isotope systematics can be reset at temperatures of $>$ ca. $100{ }^{\circ} \mathrm{C}$. To model whether the reconstructed temperatures represent calcite precipitation or closed-system resetting, the precipitation age must be known. LA-ICP-MS U-Pb dating of calcite is a recently developed approach to direct dating of calcite and can provide precipitation ages for modelling clumped-isotope systematics in calcite veins. In this study, clumped-isotope and LA-ICP-MS U-Pb calcite analyses were combined in basalt-hosted calcite veins from three settings in Scotland. Samples from all three localities yielded precipitation temperatures of ca. $75-115^{\circ} \mathrm{C}$ from clumped-isotope analysis, but veins from only two of the sites were dateable, yielding precipitation ages of $224 \pm 8 \mathrm{Ma}$ and $291 \pm 33 \mathrm{Ma}(2 \sigma)$. Modelling from the dated samples enabled confident interpretation that no closed-system resetting had occurred in these samples. However, the lack of a precipitation age from the third location meant that a range of possible thermal histories had to be modelled meaning that confidence that resetting had not occurred was lower. This highlights the importance of coupling clumped-isotope thermometry and LA-ICP-MS U-Pb calcite dating in determining the temperature of hydrothermal fluids recorded in calcite veins. This paired approach is shown to be robust in constraining the timing and precipitation temperature of calcite formation, and thus for tracking hydrothermal processes.
\end{abstract}

Keywords Clumped isotopes · Calcite veins $\cdot$ LA-ICP-MS calcite U-Pb dating $\cdot$ Hydrothermal $\cdot$ Geothermal

Communicated by Jochen Hoefs.

Electronic supplementary material The online version of this article (https://doi.org/10.1007/s00410-019-1599-x) contains supplementary material, which is available to authorized users.

J. M. MacDonald

john.macdonald.3@glasgow.ac.uk

1 School of Geographical and Earth Sciences, University of Glasgow, Glasgow G12 8QQ, UK

2 The Hunterian, University of Glasgow, Glasgow G12 8QQ, UK

3 Geochronology and Tracers Facility, British Geological Survey, Environmental Science Centre, Keyworth NG12 5GG, UK

4 Department of Earth Science and Engineering, Imperial College London, Prince Consort Road, London SW7 2AZ, UK

5 NERC Isotope Community Support Facility, Scottish Universities Environmental Research Centre, Rankine Avenue, Scottish Enterprise Technology Park, East Kilbride G75 0QF, UK

\section{Introduction}

Calcite veins are a common product of hydrothermal fluid circulation. Investigation of their isotope systematics using recent proxies such as clumped-isotope palaeothermometry (e.g., Eiler 2007) can enable reconstruction of fluid temperature and source. Clumped-isotope thermometry determines the precipitation temperature of carbonate minerals such as calcite (e.g., Eiler 2007, 2011; Schauble et al. 2006; Swart 2015). It utilises the temperature dependence of the formation of the bond between two rare heavy isotopes $\left({ }^{13} \mathrm{C}\right.$ and ${ }^{18} \mathrm{O}$ ) within the carbonate anion; the abundance of anions with ${ }^{13} \mathrm{C}-{ }^{18} \mathrm{O}$ bonds is proportional to mineral precipitation temperature (e.g., Eiler 2007; Schauble et al. 2006). In a solid carbonate mineral, such as calcite, isotope exchange ceases at the time of crystallisation. Therefore, the abundance of mass $47 \mathrm{CO}_{2}$ in calcite will 'lock in' the temperature of crystallisation. Clumped-isotope values are expressed using the $\Delta_{47}$ notation which can be calibrated against 
temperature using carbonate precipitated at known temperatures (e.g., Huntington, et al. 2009). This thermodynamic derivation of temperature from clumped isotopes gives it significant advantages over the application of traditional $\delta^{18} \mathrm{O}$ palaeothermometry to hydrothermal calcite veins, where the source fluid $\delta^{18} \mathrm{O}$ cannot easily be estimated.

Calcite which has resided in the subsurface at high temperatures (ca. $>100{ }^{\circ} \mathrm{C}$ ) for a long period (ca. > $100 \mathrm{Myr}$ ) is susceptible to solid-state bond reordering (Henkes et al. 2014; Passey and Henkes 2012; Shenton et al. 2015; Stolper and Eiler 2015). Passey and Henkes (2012) and Henkes et al. (2014) heated calcite samples to $350-450{ }^{\circ} \mathrm{C}$ under dry conditions which drove the sample $\Delta_{47}$ values towards the ambient heating temperature as the duration of heating increased, with $\Delta_{47}$ values re-equilibrating faster in the samples subjected to higher ambient temperatures. Given a sufficiently high temperature and sufficient time, bonds within carbonate isotopologues will re-equilibrate slowly to reach equilibrium with ambient burial temperatures. Passey and Henkes (2012) interpreted a two-stage bond reordering process of an initial phase of defect annealing followed by solid-state diffusion. Stolper and Eiler (2015) proposed different mechanisms: an initial rapid change of $\sim 1-40{ }^{\circ} \mathrm{C}$ at ambient temperatures of $\sim 75-120^{\circ} \mathrm{C}$ sustained for $\sim 100 \mathrm{Myr}$ due to the diffusion of isotopes through the crystal lattice; after a period of stability, a secondary stage of slow isotope exchange reactions between adjacent carbonate groups at $>\sim 150{ }^{\circ} \mathrm{C}$ sustained for $>\sim 100 \mathrm{Myr}$ which may bring the clumped-isotope temperatures to the ambient temperature.

In igneous-hosted hydrothermal systems, calcite veins may be forming at relatively high temperatures and ambient rock temperatures may be high enough to initiate clumpedisotope bond reordering. Modelling of bond reordering using thermal history reordering models (THRMs) (Shenton et al. 2015) requires some knowledge of the thermal history of the modelled material, including a starting age. Calculations of the evolution of $\Delta_{47}$ values at time steps throughout this thermal history are made using reaction kinetics determined from experimental work (Henkes et al. 2014; Passey and Henkes 2012; Stolper and Eiler 2015).

To run THRMS a start time must be known-this is the precipitation age of the calcite. Running THRMS for calcite veins is challenging, as the absolute age of vein precipitation can be difficult to constrain. As veins precipitate after the host rock, dateable minerals in the host rock can only give a maximum age at best. However, recent advances have enabled calcite dating using the $\mathrm{U}-\mathrm{Pb}$ system via a laser-ablation inductively coupled-plasma mass spectrometry (LA-ICP-MS) setup. This approach allows dating of carbonate materials older than can be dated with U-series or radiocarbon methods. Carbonate minerals such as calcite have been dated by U-Pb using dilution methods (ID-IRMS), although such studies have focussed on carbonates of meteoric origin (e.g., Pickering et al. 2010;
Woodhead et al. 2006; Woodhead and Pickering 2012). This is because these generally have high enough ${ }^{238} \mathrm{U} /{ }^{204} \mathrm{~Pb}(\mu)$ contents for precise $\mathrm{U}-\mathrm{Pb}$ dating, compared to carbonates derived from other sources (Rasbury and Cole 2009). For calcite, where high $\mu$ regions occur on a sub-mm scale, such as hydrothermal calcite, a method with high spatial precision such as LA-ICP-MS is critical for targeting these high $\mu$ areas, where the average $\mu$ across the much larger area that would be required for ID-IRMS dating is not high enough (Roberts et al. 2017). Li et al. (2014), Godeau et al. (2018) and Pisapia et al. (2018) have applied LA-ICP-MS U-Pb dating to investigate the timing of diagenetic calcite cements. Roberts and Walker (2016), Ring and Gerdes (2016), Goodfellow et al. (2017), Hansman et al. (2018), Nuriel et al. (2017) and Parrish et al. (2018) have all dated syn-faulting fracture-filling calcite to constrain the timing of brittle deformation in various settings. Coogan et al. (2016) and Drake et al. (2017) dated hydrothermal veins in the oceanic and continental crust, respectively, to address processes involving the carbon cycle. Burisch et al. $(2017,2018)$ and Walter et al. (2018) dated carbonate-bearing veins to assess the origin and timing of ore-forming fluids.

There have been very few studies combining LA-ICP-MS $\mathrm{U}-\mathrm{Pb}$ dating of calcite with clumped isotopes to date. Methner et al. (2016) combined these two methods to fingerprint Eocene hyperthermals recorded in soil carbonates in the North American continental interior, while Lawson et al. (2017) deciphered basin diagenesis through applying this approach to carbonate cements. Mangenot et al. (2018) combined LA-ICPMS U-Pb calcite dating with clumped-isotope thermometry on limestones and dolostones and Pagel et al. (2018) on breccias and veins from the Paris Basin. These studies all involved sedimentary carbonates of known age or low-temperature settings.

In potentially higher temperature settings, such as igneoushosted hydrothermal calcite veins, where the absolute age of calcite veins is not known, it is essential to run THRMs to determine whether bond reordering has occurred or whether clumped isotopes are recording the temperature, and source, of the hydrothermal fluid. In this study, we combine clumped-isotope palaeothermometry and LA-ICP-MS calcite U-Pb dating and apply it to hydrothermal calcite veins for the first time. We compare dated and undated veins to highlight the importance of combining both analytical techniques to increase confidence in interpretation of temperatures reconstructed from clumpedisotope analysis of hydrothermal calcite veins.

\section{Geological setting and sample characterisation}

Calcite veins from three sites in Scotland were analysed for this study: Arran, Loanhead, and Mull (Fig. 1a). On Arran, two samples-AR08 and AR09-of basalt-hosted 
calcite veins were taken from the ca. 335-329 Ma Lower Carboniferous Clyde Plateau Volcanic Formation (Monaghan and Pringle 2004) on the foreshore at Corrie (Fig. 1b, Supplementary Data Table 1). The samples are from the reddened upper part of the sequence, which is heavily veined with calcite, and primary silicate minerals are pervasively altered. The lower part of the sequence, however, preserves fresh olivine, clinopyroxene and rarer plagioclase. Later, Palaeogene faults, fractures, and deformation bands are associated with the emplacement of the nearby ca. 60 Ma North Arran Granite (Woodcock and Underhill 1987). The thermal influence from the emplacement of the North Arran Granite was low (England 1988; Stevenson and Grove 2014) and samples were taken from beyond this. At Corrie, a generally N-S trending set of veins are offset by later generally $\mathrm{E}-\mathrm{W}$-trending veins (Fig. 2a); sample AR08 (Fig. 2b) belongs to the $\mathrm{N}-\mathrm{S}$ set of veins, while sample AR09 (Fig. 2c) belongs to the E-W set. The basalt host rock adjacent to the veins is highly altered by fluid circulation in both samples, with quartz, chlorite, and haematite present. Both samples exhibit a mix of calcite morphologies with fibrous veins (Fig. 3a), cockade-like breccia textured veins (e.g., Cox and Munroe 2016) (Fig. 3b), and very coarse blocky calcite veins all present (Fig. 3c).

The sample from Loanhead-JF7A-taken from Loanhead Quarry, Beith, (Fig. 1c, Supplementary Data Table 1) is a broadly NW-SE-trending calcite vein and is also hosted in basalt lavas of the Lower Carboniferous Clyde Plateau Volcanic Formation. However, at this locality, the basalts are pervasively altered, showing a complex assemblage of epidote, prehnite, calcite, barite, and a wide range of zeolites (Fig. 2d) (Gribble 1992). Most of this is assumed to be near contemporaneous with the volcanism. A dyke has locally metamorphosed those early assemblages to give grossular garnet-bearing assemblages in its contact zones. This was avoided during sampling. The calcite veins have a very coarse blocky texture (Fig. 3d) or a fine sparry texture (Fig. 3e).

The Mull sample (MU04) is from the Mull Plateau Lava Formation, dated at ca. $60.5 \mathrm{Ma}$ (Emeleus and Bell 2005). The lavas in this area were mapped by Walker (1970) as being in the 'low-temperature carbonate zone', defined by Walker (1970) as representing amygdale filling with calcite and perhaps reflecting a relatively thin lava pile. The sample is from a sub-horizontal vein (Fig. 2e) of coarse sparry calcite (Fig. 3f) taken from a road cutting just south of Tobermory (Fig. 1d, Supplementary Data Table 1). Mafic minerals within the host olivine basalt are heavily altered adjacent to the calcite vein, although plagioclase appears relatively fresh.

\section{Methods}

Clumped-isotope measurements were made in the Qatar Stable Isotope Laboratory at Imperial College London. Samples were powdered using a dental drill. 5-7 $\mathrm{mg}$ of sample powder was reacted under vacuum with $105 \%$ orthophosphoric acid at $90{ }^{\circ} \mathrm{C}$ for $10 \mathrm{~min}$. Water generated during the reaction was separated from the produced $\mathrm{CO}_{2}$ by trapping in liquid nitrogen then swapping the liquid nitrogen for an ethanol-liquid nitrogen mixture held at $\sim 90{ }^{\circ} \mathrm{C}$ (Davies and John 2017). The water remained frozen in the ethanol-liquid nitrogen mixture, while the $\mathrm{CO}_{2}$ was passed through a Poropak Q chromatography trap held at $-35{ }^{\circ} \mathrm{C}$. The purified $\mathrm{CO}_{2}$ was measured on a Thermo Fisher MAT 253 isotope ratio mass spectrometers (MS Pinta, Supplementary Data Table 2) using dual inlet mode with a measurement time of $\sim 2.5 \mathrm{~h}$. Only samples with $\Delta_{48}$ and $\delta_{48}$ values that fall within $1 \%$ of the heated gas line $\left(\Delta_{48}\right.$ Offset) and had a 49 parameter of $<0.2$ were accepted, based on Huntington et al. (2009), John and Bowen (2016) and Davies and John (2017). Mass spectrometer non-linearity was corrected for using a 30-day moving average of heated gases based on methods described in Huntington et al. (2009). All $\Delta_{47}$ values are reported in the carbon dioxide equilibrated scale (Dennis, et al. 2011) using a secondary transfer function based on Carrara Marble, ETH-2 \& ETH-3 (Bernasconi et al. 2018; Meckler et al. 2014) and heated gases. Carrara Marble $\Delta_{47}$ averaged $0.416 \pm 0.038 \%$ \% $(2 \sigma, n=3)$, ETH- $2 \Delta_{47}$ averaged $0.316 \pm 0.020 \% \circ(2 \sigma, n=42)$, and the ETH-3 standard averaged $0.725 \pm 0.016 \%$ \% $(2 \sigma, n=43)$ during the analytical window. Following correction to the absolute reference frame, the empirical acid fractionation factor of $+0.082 \%$ o (Defliese et al. 2015) was added to the $\Delta_{47}$ value to bring the data into the $25{ }^{\circ} \mathrm{C}$ scale used in calibrations. This acid fractionation factor is consistent with internal laboratory tests at Imperial College London. All standard and sample data are given in the Supplementary Data Table 2. The calibration of Davies and John (2019), which includes some of the original Kluge et al. (2015) calibration points, modified to account for the ${ }^{17} \mathrm{O}$ parameters in Brand et al. (2010), was used to convert $\Delta_{47}$ into temperature. Temperature data are presented both in the conventional fashion with one standard error and at a $95 \%$ confidence level. Source fluid $\delta^{18} \mathrm{O}$ values were calculated using the carbonate-water equilibrium fractionation factor of Kim and O' Neil (1997) and reported in the Vienna Standard Mean Ocean Water (VSMOW) scale, while measured $\delta^{18} \mathrm{O}$ and $\delta^{13} \mathrm{C}$ values are reported in the Vienna PeeDee Belemnite (VPDB) scale. Additional $\delta^{13} \mathrm{C}$ and $\delta^{18} \mathrm{O}$ measurements were made using VG OPTIMA mass spectrometer at the Scottish Universities Environmental 

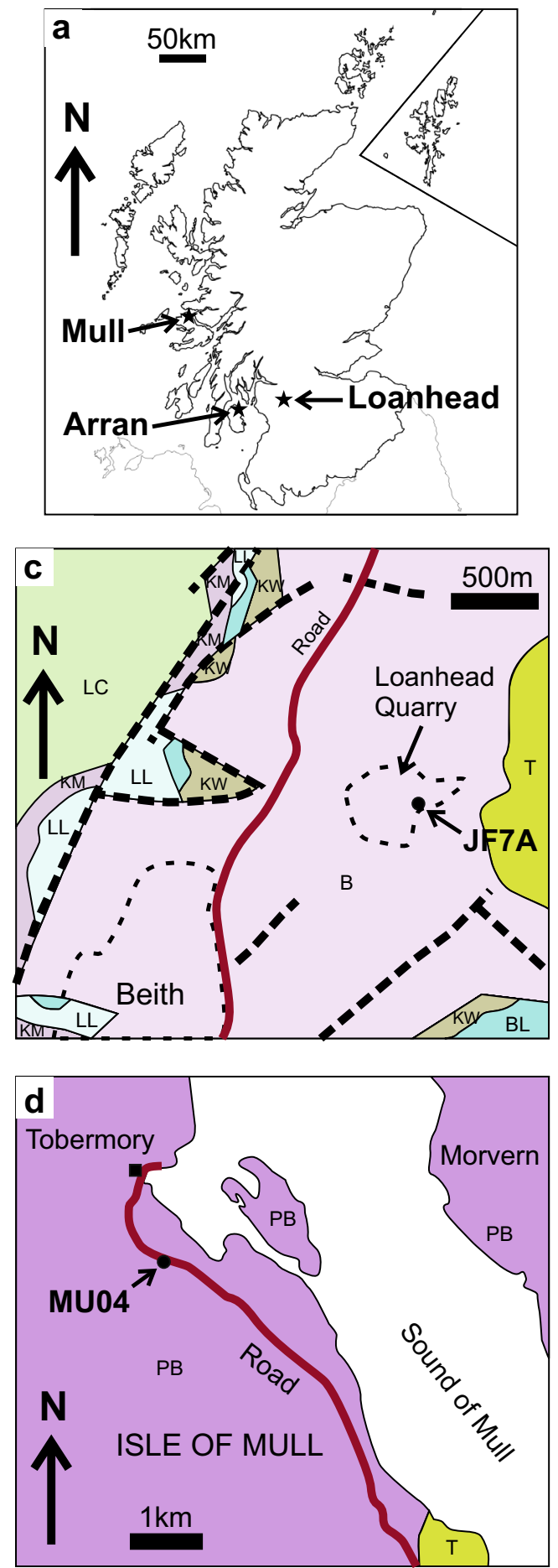

Fig. 1 Location and geology maps: a locations of the 3 Scottish casestudy sites, where samples were taken; b geological map of the Corrie area on the Isle of Arran; $\mathbf{c}$ geological map of the area around

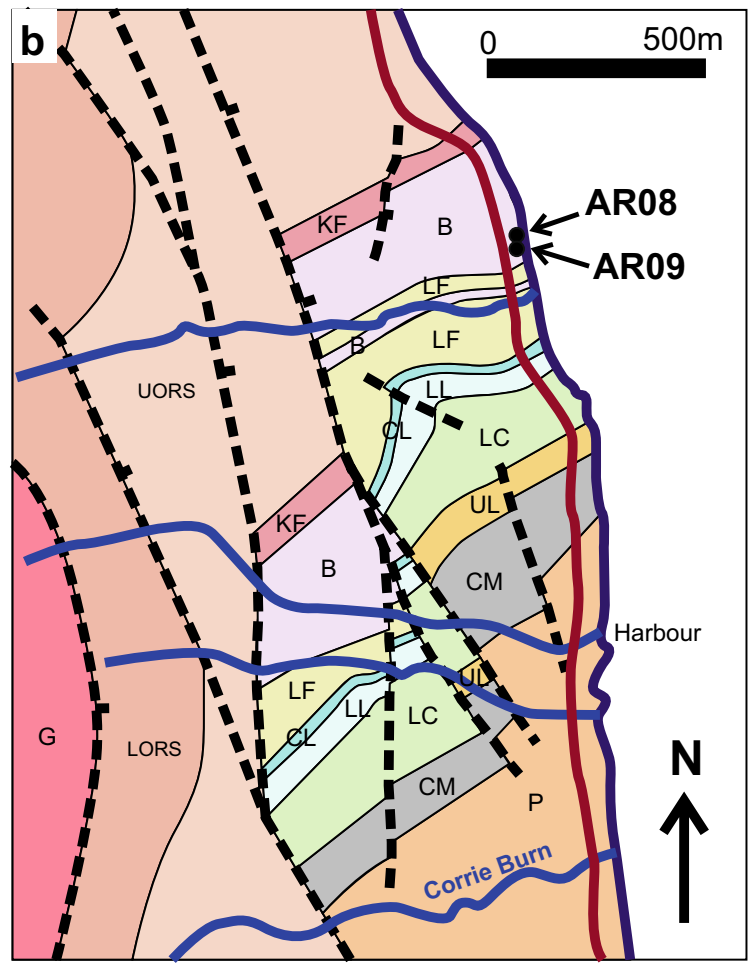

\section{LEGEND}

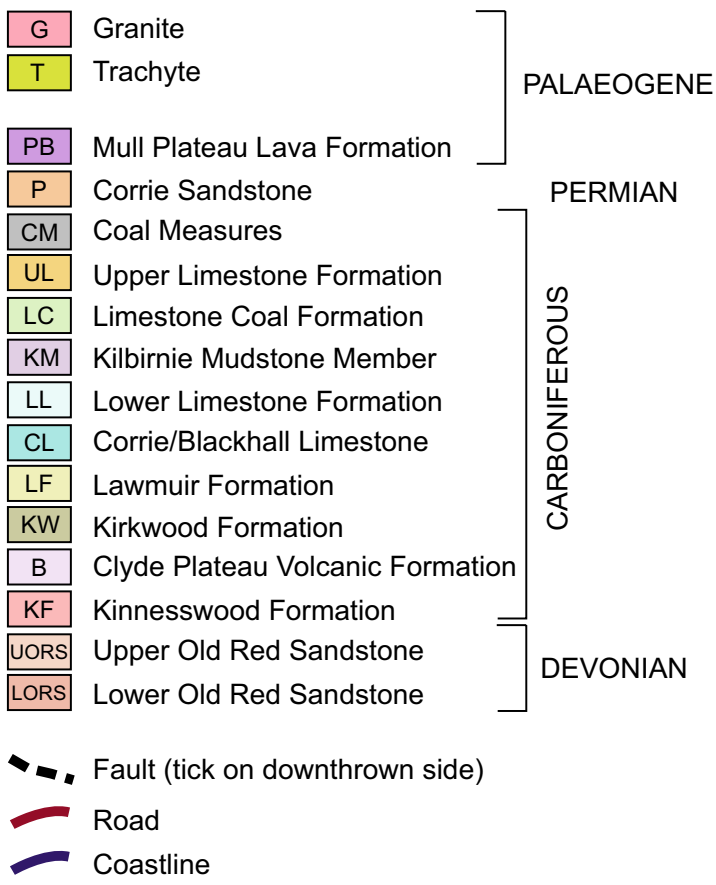

Loanhead Quarry, Ayrshire; d geological map of the area around Tobermory on the Isle of Mull 
Fig. 2 Field photographs showing samples taken: a photograph showing cross-cutting calcite veins, Isle of Arran site. Sample AR08 belongs to the N-Soriented set and is older than sample AR09 from the E-Wtrending set; $\mathbf{b}-\mathbf{e}$ photographs of samples AR08, AR09, JF7A, and MU04, respectively (a) shows N-S trending vein offset by later E-W trending vein; AR08 belongs to the $\mathrm{N}-\mathrm{S}$ set and so is slightly older than AR09 which belongs to the E-W set
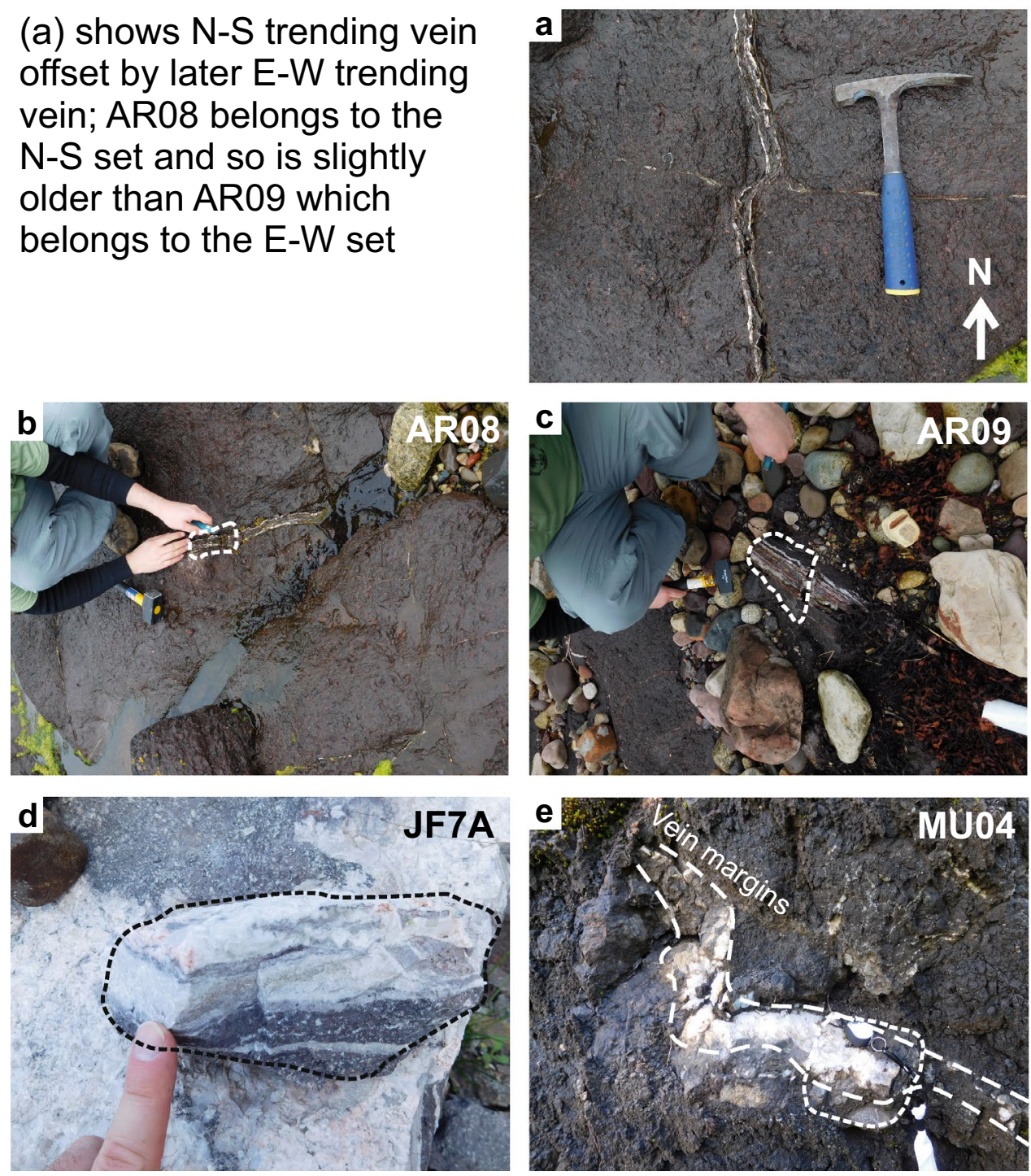

\section{Arran}

graphs (transmitted light optical microscope) showing the nature of the calcite veins: a fibrous calcite vein in sample AR08 (XPL); b 'cockade'-like breccia texture in calcite vein in sample AR09 (PPL); c vein in sample AR09 of large sparry calcite (XPL); $\mathbf{d}$ vein in sample JF7A of large sparry calcite (PPL); e vein in sample JF7A of fine sparry calcite; f) vein in sample MU04 of large sparry calcite (PPL). $B$ denotes host basalt

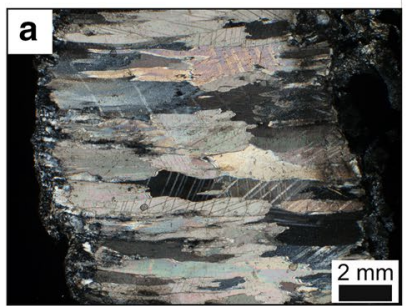

\section{Loanhead}

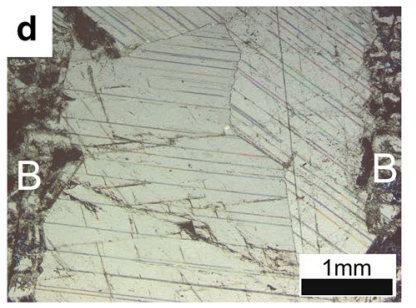

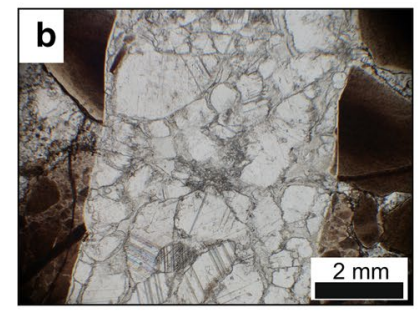

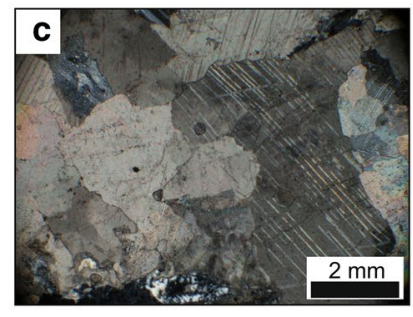

Mull
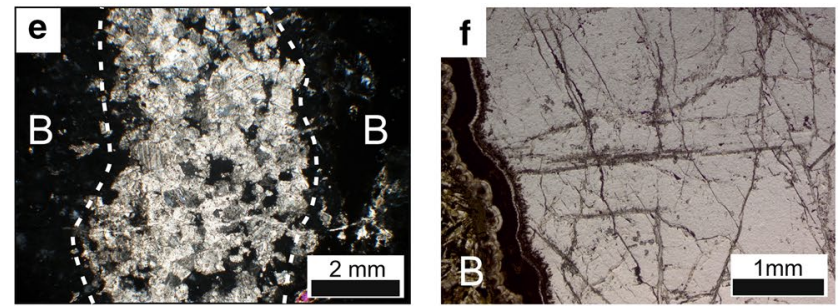
Research Centre (Supplementary Data Table 3). For this, $1 \mathrm{mg}$ of powdered sample was digested in $100 \%$ phosphoric acid in a $25{ }^{\circ} \mathrm{C}$ water bath. A marble standard, as well as replicate analyses, were used to calibrate the results, with reproducibility in $\delta^{13} \mathrm{C}$ of $-9.2 \pm 0.1 \%$ and $\delta^{18} \mathrm{O}$ of $-15.0 \pm 0.1 \%$ \% $(2 \sigma)$.

LA-ICP-MS U-Pb calcite dating (Supplementary Data Table 4) was conducted at the Geochronology \& Tracers Facility, NERC Isotope Geosciences Laboratory (Nottingham, UK) using a New Wave Research 193UC excimer laser-ablation system, coupled to a $\mathrm{Nu}$ Instruments Attom single-collector sector-field ICP-MS following the methods outlined by Roberts and Walker (2016). Samples were pre-ablated with a $150 \mu \mathrm{m}$ spot for 30 pulses. Full ablation conditions comprise a $100 \mu \mathrm{m}$ spot for $30 \mathrm{~s}$ at $10 \mathrm{~Hz}$ and a fluence of ca. $8 \mathrm{~J} / \mathrm{cm}^{2}$. A gas blank of ca. $60 \mathrm{~s}$ is measured at the beginning of each run. Normalisation uses NIST614 for ${ }^{207} \mathrm{~Pb} /{ }^{206} \mathrm{~Pb}$ and $\mathrm{WC}-1$ for ${ }^{206} \mathrm{~Pb} /{ }^{238} \mathrm{U}$, with data reduction and uncertainty propagation following Roberts et al. (2017) and the recommendations of Horstwood et al. (2016), and conducted using an in-house spreadsheet and the $\mathrm{Nu}$ Attolab Time Resolved Acquisition software. Age calculations and plotting were conducted using Isoplot 4.15 (Ludwig 2012). Duff Brown Tank limestone was analysed during each session as a validation material; a pooled age of $63.0 \pm 1.2 \mathrm{Ma}(2 \sigma, \mathrm{MSWD}=2.1)$ was obtained, which is within uncertainty of the published age of $64.04 \pm 0.67 \mathrm{Ma}$ (Hill et al. 2016).

\section{Results}

$\delta^{13} \mathrm{C}, \delta^{18} \mathrm{O}$ and clumped-isotope values, LA-ICP-MS U-Pb ages, and their locations on the samples are shown in Fig. 4. $\delta^{13} \mathrm{C}$ and $\delta^{18} \mathrm{O}$ values from Arran samples AR08 and AR09 show some variability within the veins with $\delta^{13} \mathrm{C}$ values ranging from -4.7 to $-11.7 \%$ but with the vast majority clustering around ca. -10 to $-12 \%$ (Supplementary Data Table 3, Figs. 4a, b, 5). Clumped-isotope analysis of a fibrous calcite vein from AR08 gave a temperature of $77 \pm 7{ }^{\circ} \mathrm{C}( \pm 1 \mathrm{SE})$, from which a source fluid $\delta^{18} \mathrm{O}$ value of $8.9 \pm 1.0 \%$ was calculated (Table 1, Figs. $4 \mathrm{a}, \mathrm{b}, 6$ ). The same vein was dated to $224 \pm 8$ Ma (Figs. $4 a, 7 a$ ). A clumped-isotope temperature of $116 \pm 2{ }^{\circ} \mathrm{C}$ was obtained from a very coarse blocky calcite vein in sample AR09, from which a source fluid $\delta^{18} \mathrm{O}$ value of $9.8 \pm 0.2 \%$ was calculated (Table 1, Fig. 6). No meaningful age was derived from this sample due to elevated common $\mathrm{Pb}$.

$\delta^{18} \mathrm{O}$ values from sample JF7A from Loanhead ranged from -9.5 to $-13.1 \%$, while $\delta^{13} \mathrm{C}$ fell in a wide range from -6.16 to $-38.9 \%$ (Supplementary Data Table 3, Figs. 4c, $5)$. Two clumped-isotope temperatures were derived from

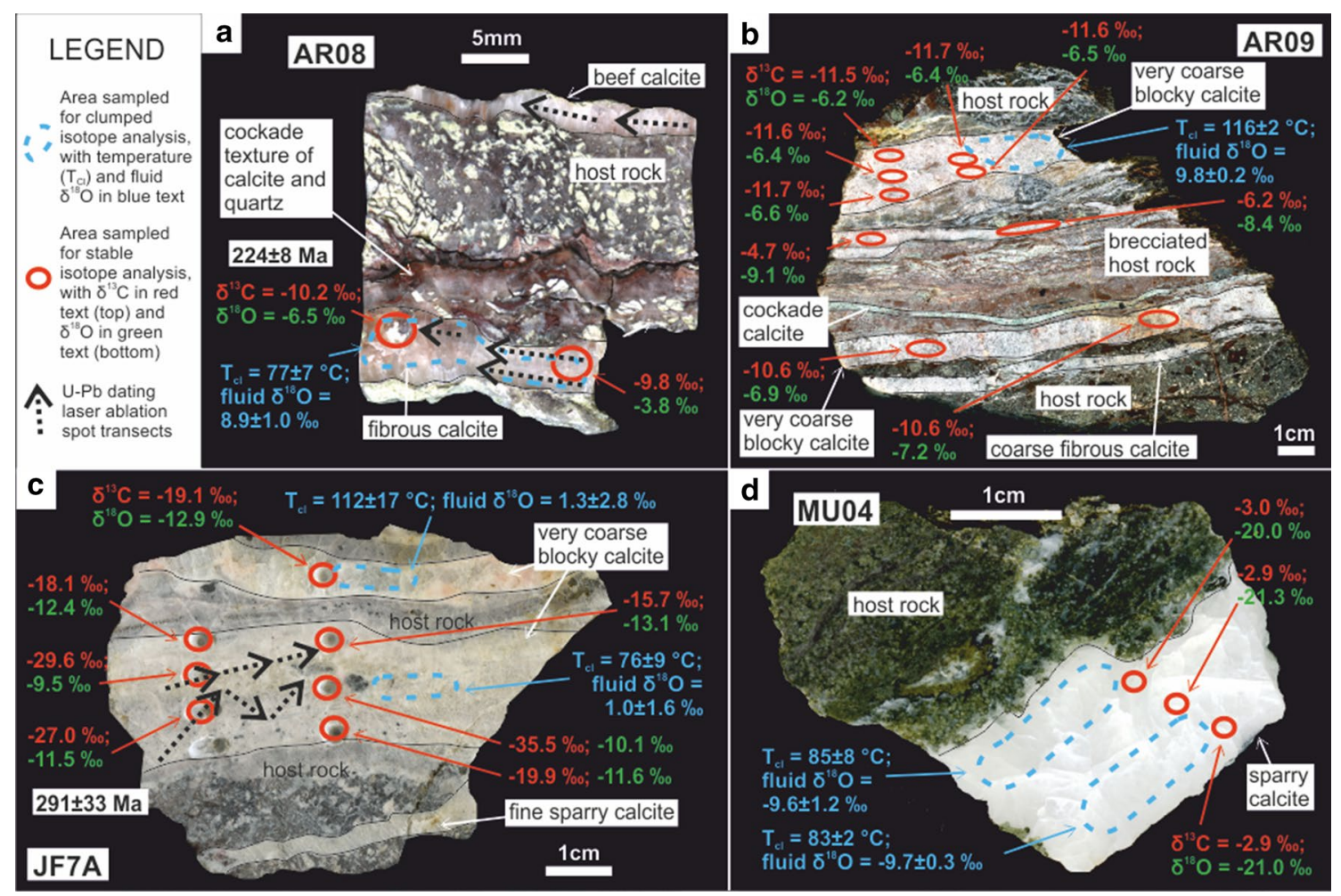

Fig. 4 Sample slices with calcite textures, $\delta^{13} \mathrm{C}, \delta^{18} \mathrm{O}$, clumped-isotope temperatures and $\mathrm{U}-\mathrm{Pb}$ ages annotated with analytical locations: a sample AR08; b sample AR09; c sample JF7A; d sample MU04 


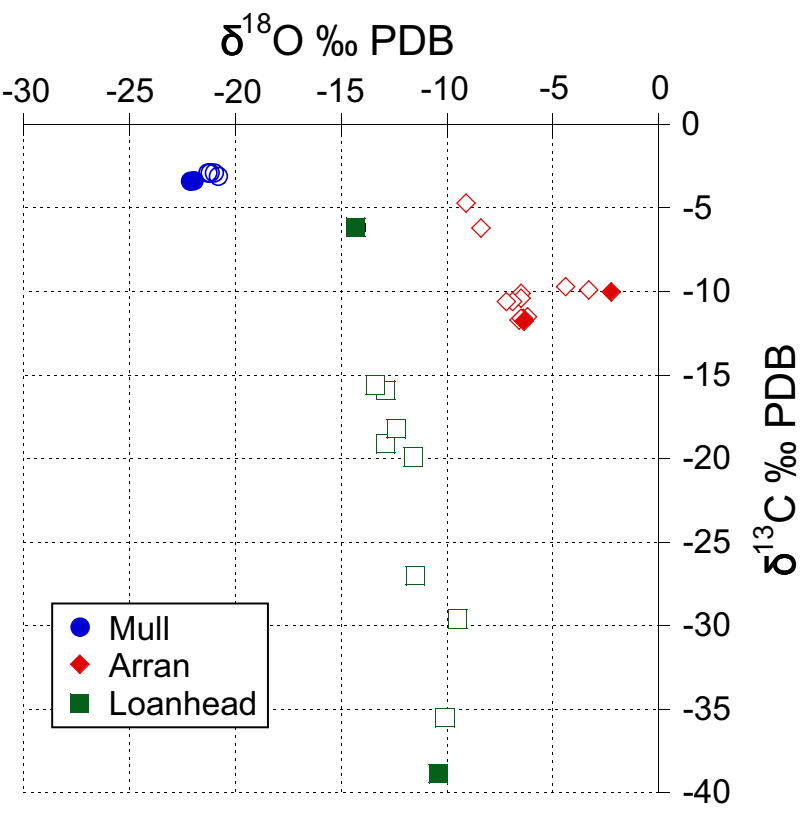

Fig. $5 \delta^{13} \mathrm{C}$ and $\delta^{18} \mathrm{O}$ values of calcite veins from the three case-study sites

this sample (both from very coarse blocky calcite veins) of $112 \pm 17{ }^{\circ} \mathrm{C}$ and $76 \pm 9{ }^{\circ} \mathrm{C}$, yielding source fluid $\delta^{18} \mathrm{O}$ values of $1.3 \pm 2.8 \%$ and $1.0 \pm 1.6 \%$, respectively (Table 1 , Figs. $4 \mathrm{c}, 6)$. The wider of the two veins, which yielded the temperature of $76 \pm 9{ }^{\circ} \mathrm{C}$, recorded an age of $291 \pm 33 \mathrm{Ma}$ (Figs. 4c, 7b).

$\delta^{13} \mathrm{C}$ and $\delta^{18} \mathrm{O}$ values from Mull sample MU04 clustered around $-3 \%$ and $-21 \%$, respectively (Supplementary Data Table 3, Figs. 4d, 5). Two clumped-isotope temperatures were derived from this sample-one from the edge of the vein and one from the centre. The vein edge analysis recorded a temperature of $85 \pm 8{ }^{\circ} \mathrm{C}$ and a source fluid $\delta^{18} \mathrm{O}$ value of $-9.6 \pm 1.2 \%$; the vein centre analysis recorded a temperature of $83 \pm 2{ }^{\circ} \mathrm{C}$ and a source fluid $\delta^{18} \mathrm{O}$ value of $-9.7 \pm 0.3 \%$ (Table 1, Figs. 4d, 6). The amount of radiogenic $\mathrm{Pb}$ in this sample was too low to yield an age.

\section{Discussion}

\section{Thermal history reordering models (THRMs)}

Calcite which has resided in the subsurface at high temperatures (ca. $>100{ }^{\circ} \mathrm{C}$ ) for a long period (ca. $>100 \mathrm{Myr}$ ) is susceptible to solid-state bond reordering (Henkes et al. 2014; Passey and Henkes 2012; Shenton et al. 2015; Stolper and Eiler 2015). Passey and Henkes (2012) and Henkes et al. (2014) heated calcite samples to $350-450{ }^{\circ} \mathrm{C}$ under dry conditions which drove the sample $\Delta_{47}$ values towards the ambient heating temperature as the duration of heating increased,

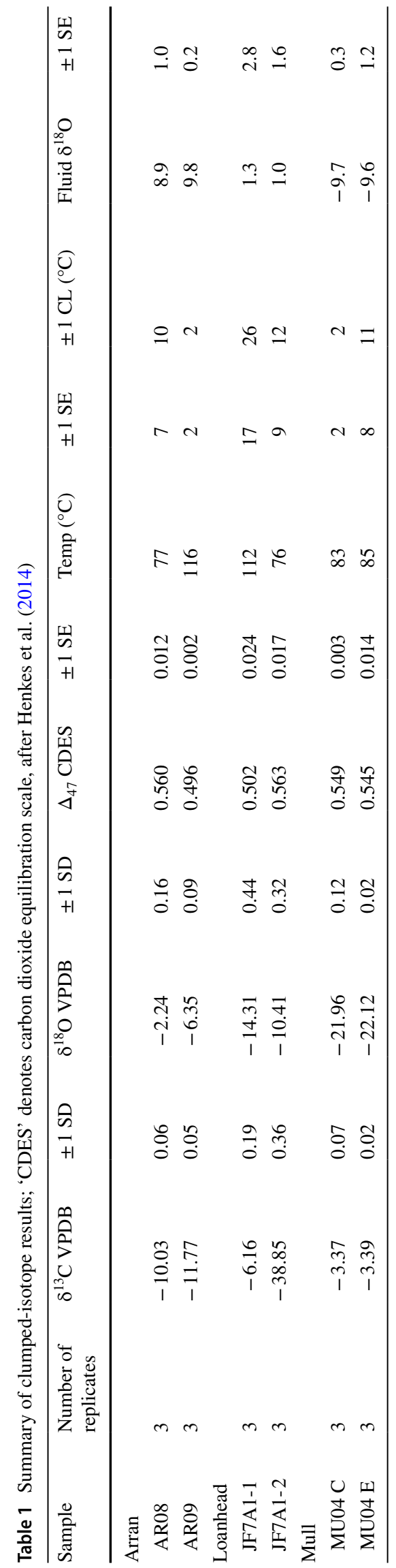




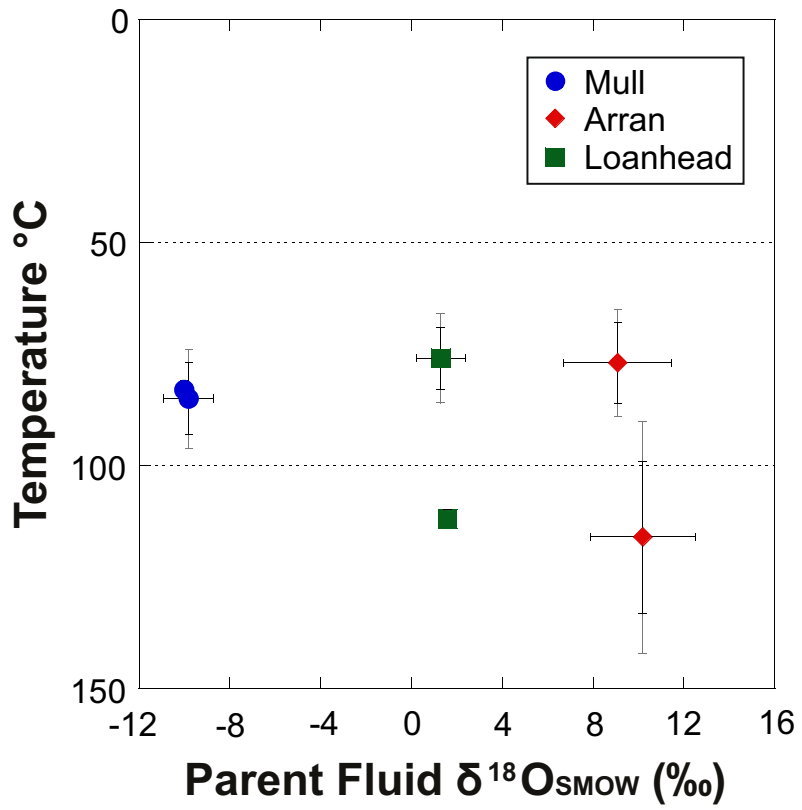

Fig. 6 Clumped-isotope temperatures and parent fluid $\delta^{18} \mathrm{O}$ values (calculated from clumped-isotope analysis) of calcite veins from the three case-study sites

with $\Delta_{47}$ values re-equilibrating faster in the samples subjected to higher ambient temperatures. Given a sufficiently high temperature and sufficient time, bonds within carbonate isotopologues will re-equilibrate slowly to reach equilibrium with ambient burial temperatures. Passey and Henkes (2012) interpreted a two-stage bond reordering process of an initial phase of defect annealing followed by solid-state diffusion. Stolper and Eiler (2015) proposed different mechanisms: an initial rapid change of $\sim 1-40{ }^{\circ} \mathrm{C}$ at ambient temperatures of $\sim 75-120^{\circ} \mathrm{C}$ sustained for $\sim 100 \mathrm{Myr}$ due to diffusion of isotopes through the crystal lattice; after a period of stability, a secondary stage of slow isotope exchange reactions between adjacent carbonate groups at $>\sim 150{ }^{\circ} \mathrm{C}$ sustained for $>\sim 100$ Myr which may bring the clumped-isotope temperatures to the ambient temperature.

Given that the calcite $\mathrm{U}-\mathrm{Pb}$ dating indicates that the samples from Arran and Loanhead are much older than ca. 100 $\mathrm{Myr}$, and clumped-isotope thermometry yields temperatures of ca. $100{ }^{\circ} \mathrm{C}$ in some samples, it is necessary to run thermal history reordering models (THRMs, Shenton et al. 2015) to determine whether bond reordering has occurred (Supplementary Data Table 5). The THRM approach developed by Shenton et al. (2015) involves modelling temporal evolution in $\Delta_{47}$ based on kinetic parameters (e.g., activation energy, $E_{\mathrm{a}}$ and pre-exponential factor, $K_{\mathrm{o}}$ ) derived from Arrhenius regressions of experimental data from Passey and Henkes (2012). THRMs require knowledge or assumptions about the temperature history of the analysed sample. This temperature history is divided into a series of time steps with
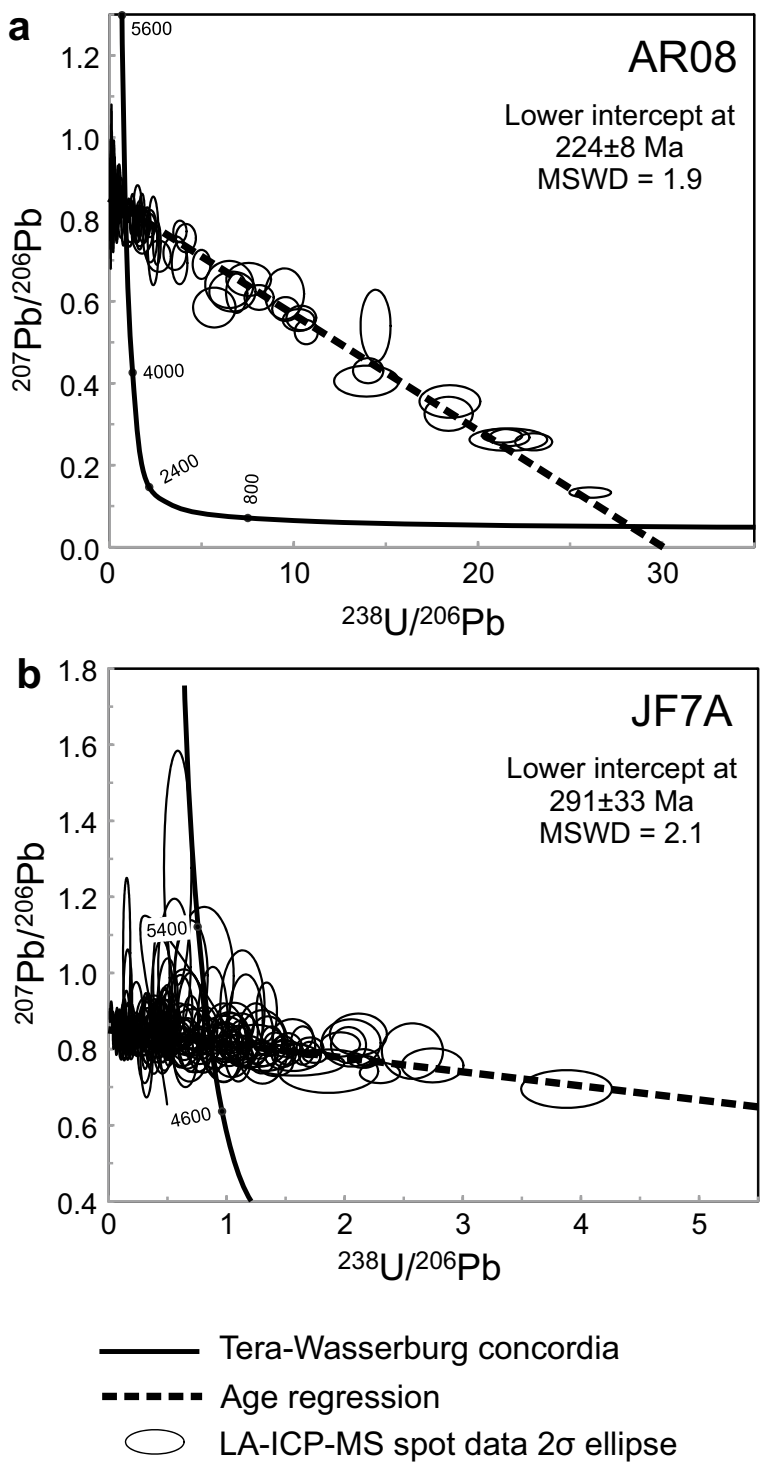

Fig. 7 Tera-Wasserburg Concordia plots, with calculated lower intercept ages representing precipitation age, from sample AR08 (a) and sample JF7A (b); each ellipse denotes $\mathrm{Pb} / \mathrm{U}$ ratios with error for each laser-ablation spot

a specified ambient temperature (converted back to $\Delta_{47}$ ) at each time step. The bond reordering reaction [reaction 13 in Passey and Henkes (2012)] is then used calculate the extent of clumped-isotope reordering during each step. The 'new' $\Delta_{47}$ value at the end of each time step is treated as the 'initial' $\Delta_{47}$ value for the next step and the model is run iteratively from the time of initial calcite precipitation to the present day (Shenton et al. 2015). In addition, calcite of different origin (e.g., brachiopods vs spar calcite vs optical calcite) were found to have different reordering kinetics (activation energy and pre-exponential factor) during laboratory experiments (Henkes et al. 2014; Passey and Henkes 2012). 
In addition to the activation energy and pre-exponential factor, the assumed initial precipitation temperature and age of precipitation are input to run the model. For sedimentary or biogenic calcite, an assumed surface temperature of ca. $25{ }^{\circ} \mathrm{C}$ (or a more accurate one based on species in biogenic calcites) is used (Henkes et al. 2013, 2014). For calcite veins, this is challenging as one cannot assume an initial precipitation temperature. In the THRMs run for the samples from Arran and Loanhead, we assumed that the temperature reconstructed from clumped-isotope analysis was the initial precipitation temperature and forward modelled using an ambient thermal history to determine if bond reordering had occurred. For this approach, it is essential to know the calcite precipitation age so as to know when to forward model the $\Delta_{47}$ values from. This highlights the importance of undertaking LA-ICP-MS U-Pb calcite dating: calcite veins are often likely to have experienced temperatures $>100{ }^{\circ} \mathrm{C}$ and may be $>100$ Myr old. As there is a good chance that bond reordering will have occurred, it is important to run THRMs with LA-ICP-MS U-Pb calcite dating, such that clumped-isotope temperatures can be interpreted with confidence.

THRMs were run for the Arran and Loanhead samples using thermal evolution modelling from apatite fission track and apatite helium data from sample Sct-2 of Cogne et al. (2016), and the calcite precipitation ages derived in this study from LA-ICP-MS calcite U-Pb dating. Kinetic parameters for both optical and spar (labile and refractory) calcite from Passey and Henkes (2012) were used, but the choice of kinetic parameters did not affect the model output. This is because the THRMs for the Arran and Loanhead samples indicate that no bond reordering took place in any of these samples (Fig. 8a, b). The age from sample AR08 was used for the THRM for AR09; as field relationships indicated AR09 was younger than AR08, the precipitation age of AR08 is a 'worst-case' scenario. In addition, the THRM did not incorporate a thermal effect from the intrusion of the North Arran Granite at ca. $60 \mathrm{Ma}$, as the samples were taken from beyond the granite's thermal influence (England 1988; Stevenson and Grove 2014).

Construction of a THRM for Mull sample MU04 is more complex as the amount of radiogenic $\mathrm{Pb}$ in this sample was too low to yield an age. In addition, there is uncertainty about the original thickness of the host lava pile and the role of the nearby Mull Central Complex. Walker (1970) interpreted that the Mull Central Complex, dated at $58.48 \pm 0.18 \mathrm{Ma}$ (Chambers and Pringle 2001), would not have been responsible for fluid circulation beyond a few kilometres of the central complex (sample MU04 is from $10 \mathrm{~km}$ away). Instead, he suggests that the fluids responsible for carbonate amygdale and vein filling may have been influenced by the similar age Ardnamurchan Centre to the north. Assuming relatively rapid erosion of the host basalt, the sample is interpreted to have been at near-surface conditions by ca. $50 \mathrm{Ma}$. If bond reordering did indeed occur, to result in the measured temperature of $83-85{ }^{\circ} \mathrm{C}$, precipitation from fluid cooler than $85{ }^{\circ} \mathrm{C}$ at an ambient host-rock temperature of $>150{ }^{\circ} \mathrm{C}$ would be required (Fig. 8c). This scenario seems unlikely and it is, therefore, interpreted that bond reordering did not occur in these samples.

Having a measured LA-ICP-MS U-Pb calcite precipitation age of the veins from Arran and Loanhead allowed for a single THRM to be run for each, giving confidence to interpretation of the clumped-isotope temperatures. In Mull, where a vein precipitation age was lacking, multiple THRMs were run for different scenarios, and while it was interpreted that bond reordering was unlikely to have occurred, it could not be determined that the clumped-isotope temperature was the vein precipitation temperature. This highlights the importance of running THRMs with LA-ICP-MS U-Pb calcite dating, such that clumped-isotope temperatures can be interpreted with confidence.

\section{Calcite vein formation}

Given that the THRMs indicate that no bond reordering occurred in the samples, the clumped-isotope data, together with the calcite dating and field and petrographic analyses, can be integrated to provide insight into hydrothermal fluid conditions in the case-study regions.

\section{Arran}

The fibrous calcite vein in sample AR08 precipitated at $224 \pm 8 \mathrm{Ma}$, in the late Triassic. At this time, subsidence and extension in western Scotland led to a relative sea-level rise and a transition from terrestrial to marine sedimentation (Glennie 2002; Warrington and Ivimey-Cook 1992); this change in tectonic regime was likely the cause of fracture opening the formation of the veins at Corrie. The coarse blocky calcite vein in sample AR09 could not be dated, but field relationships show that it is cross-cutting the vein from which AR08 was sampled (Fig. 2a). Given the approximately $90^{\circ}$ difference in orientation between the veins in AR08 and AR09, and the difference in crystal shape between the two veins, suggests that there may have been a significant time gap between their respective formation. Furthermore, the increase in temperature from $77 \pm 7{ }^{\circ} \mathrm{C}$ to $116 \pm 2{ }^{\circ} \mathrm{C}$ between the two samples indicates a period of time for heating of the fluid. However, the fact that the calculated source fluid $\delta^{18} \mathrm{O}$ values of the two samples are within uncertainty of each other indicates a common fluid source. The thermal evolution determined by Cogne et al. (2016) for this area shows that burial temperatures did not exceed $\sim 80{ }^{\circ} \mathrm{C}$ for rocks now at the surface, and therefore, the clumped-isotope temperatures cannot reflect an ambient burial temperature. 
Fig. 8 Thermal history reordering models for samples from the three case-study sites showing the modelled evolution of clumped-isotope temperature and ambient temperature after vein precipitation

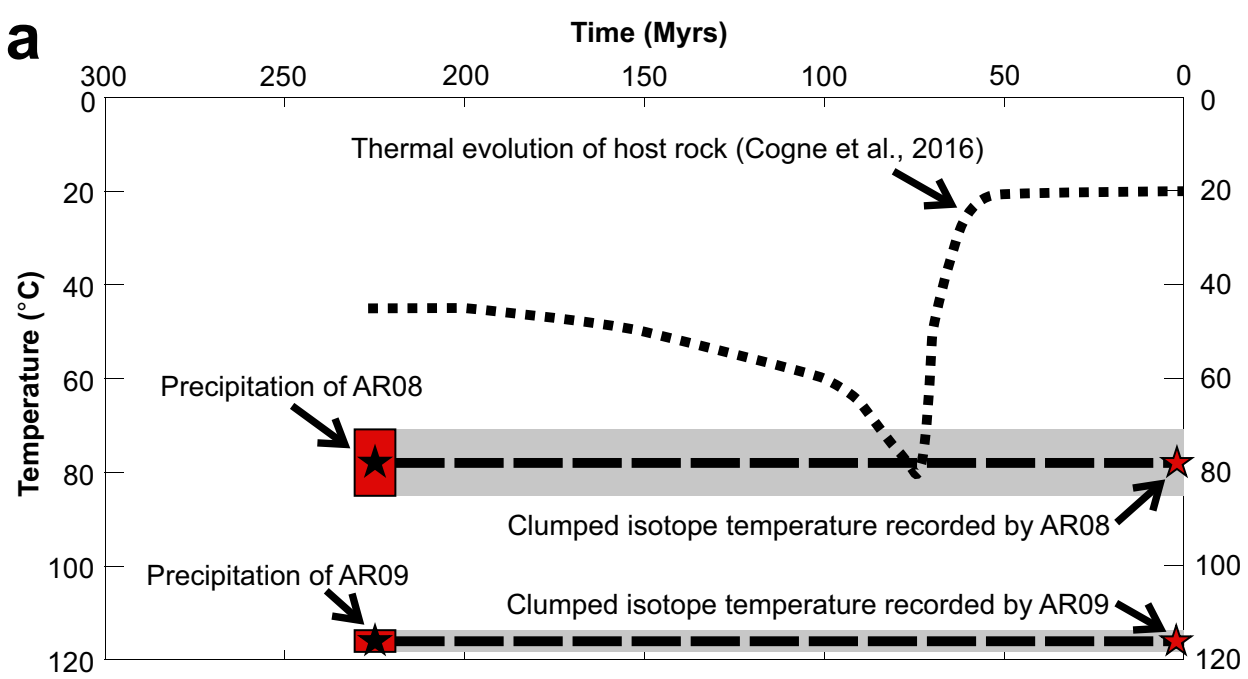

b

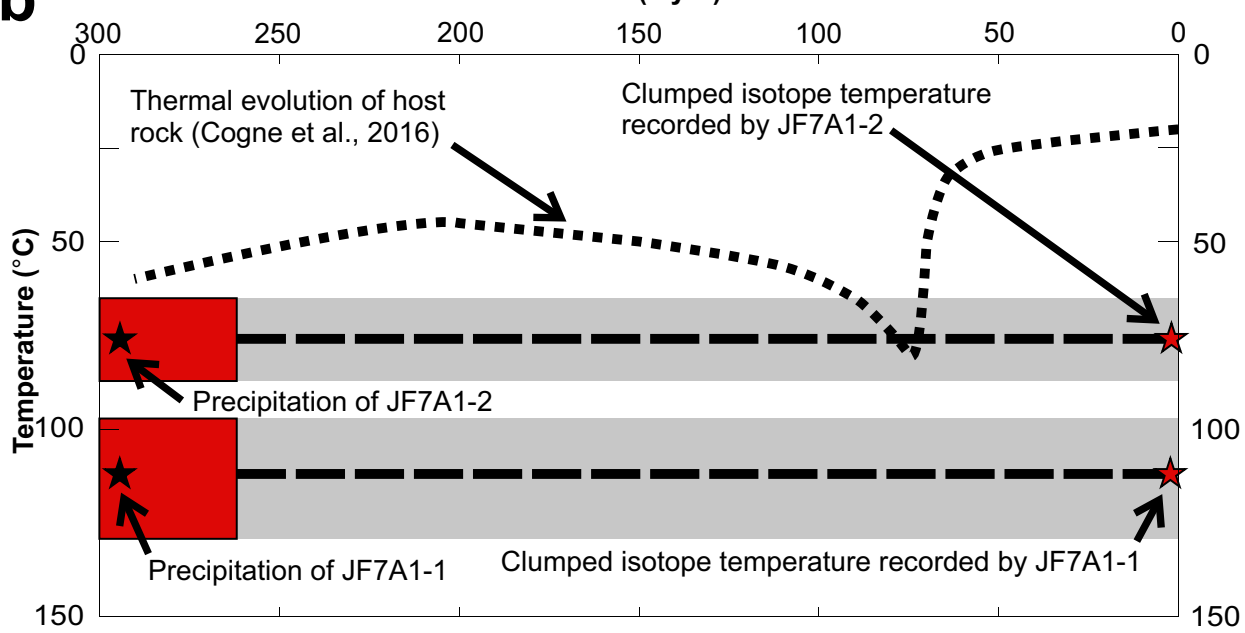


The isotopically heavy fluid $\delta^{18} \mathrm{O}$ values of ca. $9-10 \%$ could suggest a juvenile magmatic fluid source, although such fluids tend, if present at all, to make up a small proportion of geothermal fluids (Craig et al. 1963; Sharp 2007). Volcanic activity, in the form of the Clyde Plateau Lava Formation, was occurring at the time of the host-rock formation, but there is no documented volcanic or magmatic activity at ca. $224 \mathrm{Ma}$, the age of calcite precipitation (Glennie 2002). Without being able to measure the source water $\delta \mathrm{D}$ though, the presence of juvenile magmatic water cannot be conclusively discounted. A combination of magmatic and meteoric fluid sources has been documented in active geothermal systems and could be a possibility for Arran. Using clumped isotopes Lu et al. (2017) documented source fluid $\delta^{18} \mathrm{O}$ values of up to ca. $10 \%$ in the Chingshui Geothermal Field of Taiwan and suggested a mixed meteoric-magmatic fluid, with a shallow meteoric reservoir and a deep magmatic reservoir. The ca. 9-10 \%o calculated from the Arran samples falls within the typical range of 'metamorphic' waters (e.g., Rollinson 1993; Sharp 2007)—fluids buffered by metamorphic rocks-which are present (Dalradian pelites and psammites) at the surface several kilometres to the north of the Corrie sample site (British-Geological-Survey 1987) and likely underlie the host Carboniferous basalts at some depth. However, the amount of available water present in metamorphic rocks (along grain boundaries or in fluid inclusions) is very small to be of consequence as a fluid reservoir (e.g., Sharp 2007). Another possible source of the isotopically enriched source fluid for the Arran calcite veins could be highly evaporated seawater. Knauth and Beeunas (1986) modelled that a seawater evaporated $10 \times$ would attain a $\delta^{18} \mathrm{O}$ value of ca. $10 \%$. Marine transgression extended northwestwards over much of Scotland in the late Triassic (when the vein precipitated), suggesting that an evaporated seawater source is a possibility (Glennie 2002).

Perhaps, the most likely explanation for the enriched fluid $\delta^{18} \mathrm{O}$ values of ca. $9-10 \%$ is calcite precipitation in a low water-rock ratio environment from fluid which has undergone considerable water rock interaction. A purely meteoric fluid source would need to undergo a strong degree of water-rock interaction to achieve the isotopically heavy fluids calculated from the clumped-isotope analysis. Meteoric waters which have percolated down through the sedimentary and metamorphic rocks around the sample site would have been heated, circulated through, and reacted with these rocks, resulting in an elevated $\delta^{18} \mathrm{O}$ value relative to surface meteoric water values (e.g., Rollinson 1993; Sharp 2007). Evidence for water-rock interaction can clearly be seen in the alteration of the host basalt around the veins to an assemblage including hydrous minerals such as chlorite (Fig. 6).

It is possible that the calcite veins in their current form do not represent the primary fracture-filling precipitation but instead represent a later open-system recrystallisation via dissolution-reprecipitation. Such recrystallisation would reset the $\mathrm{U}-\mathrm{Pb}$ age and clumped-isotope systematics (e.g., Eiler 2007). In this scenario, the temperature at $224 \pm 8 \mathrm{Ma}$ was $77 \pm 7{ }^{\circ} \mathrm{C}$ in sample AR08 when recrystallisation of an earlier generation of fracture-filling calcite occurred. In this scenario, the fluid $\delta^{18} \mathrm{O}$ value would be buffered by the dissolution of the earlier calcite, perhaps resulting in the enriched values of ca. 9-10\% reconstructed from the Arran samples. It should be noted, however, that the calcite in sample AR08 has a fibrous texture and so is likely to represent primary precipitation during opening of a highly restricted fracture aperture (e.g., Barker et al. 2006; Oliver and Bons 2001). The later sample AR09 has a blocky texture, perhaps representing an open fracture through which flow could occur, yields a higher temperature than the fibrous vein. This is more likely to represent a fluid which was warmer than the ambient rock temperature. While it is difficult to be certain without further analysis, it is, therefore, interpreted that the Arran veins represent primary precipitation but from a fluid which has undergone significant water-rock interaction with relatively restricted flow.

\section{Loanhead}

The Variscan Orogeny gave rise to E-W extension in Northern Europe in the early Permian (Glennie 2002; Monaghan and Parrish 2006), and rift-related alkaline mafic intrusions, lavas, and breccias are widely developed in Ayrshire. One of these-the Carskeoch intrusion-has been dated via hornblende $\mathrm{Ar}-\mathrm{Ar}$ at $295 \pm 1.3 \mathrm{Ma}$ (Monaghan and Pringle 2004). An early Permian precipitation age of $291 \pm 33 \mathrm{Ma}$ was recorded from the centre of the largest coarse blocky calcite vein in sample JF7A, with a temperature of $76 \pm 9{ }^{\circ} \mathrm{C}$ also from the centre of the vein. Calcite $\delta^{18} \mathrm{O}$ values were relatively homogeneous across this and the other veins in this sample, but $\delta^{13} \mathrm{C}$ values varied widely. The most depleted $\delta^{13} \mathrm{C}$ values were from the centre of the vein, where the age and temperature were derived from; the edges of the large vein, and the smaller coarse blocky calcite vein from the same sample, recorded less depleted $\delta^{13} \mathrm{C}$ values. The precipitation temperature of the smaller coarse blocky calcite vein was significantly higher than the centre of the large one: $112 \pm 17^{\circ} \mathrm{C}$. Petrographically, the two veins are similar and there is no clear petrographic difference within the larger vein, despite the variation in $\delta^{13} \mathrm{C}$ values. Early Permian volcanic and magmatic activity is recorded in this area within error of the $291 \pm 33 \mathrm{Ma}$ age recorded from sample JF7A, and therefore, an isotopically depleted volcanic methane source is a possible for these depleted $\delta^{13} \mathrm{C}$ values (e.g., Sharp 2007). However, at the time of calcite precipitation, there may have been a significant cover thickness of Carboniferous sedimentary rocks, including extensive coal-bearing sequences of the Scottish Coal Measures 
Group (Read et al. 2002). The isotopically depleted $\delta^{13} \mathrm{C}$ values in sample JF7A could, therefore, also be explained by precipitation from groundwater with significant dissolved coal-derived methane (e.g., Des Marais 2001; Sharp 2007). Another possibility for the range in $\delta^{13} \mathrm{C}$ values may be the gradual depletion of ${ }^{13} \mathrm{C}$ from the fluid as calcite precipitation progressed, starting at the vein margins.

The fluid $\delta^{18} \mathrm{O}$ values of ca. $1 \%$ have a non-unique interpretation of fluid source. One possibility is slightly evaporated seawater which would have a slightly positive $\delta^{18} \mathrm{O}$ value (e.g., Sharp 2007). However, the palaeogeography of Scotland in the early Permian at the time of calcite precipitation at Loanhead is continental in Pangaea (Glennie 2002), and therefore, a marine fluid source can be discounted. With igneous activity occurring locally at this time (Monaghan and Pringle 2004), a mix of magmatic and meteoric fluid sources, as suggested as a possibility for the Arran samples, could result in the calculated fluid $\delta^{18} \mathrm{O}$ values of ca. $1 \%$. Lu et al. (2017) also recorded fluid $\delta^{18} \mathrm{O}$ values of ca. $1 \%$ in the Chingshui Geothermal Field of Taiwan, for which they suggested a mixed fluid, with a shallow meteoric reservoir and a deep magmatic reservoir. The most likely source for the fluids from which the calcite veins precipitated at Loanhead is interpreted to be meteoric water which has undergone some water-rock interaction. Meteoric water has negative $\delta^{18} \mathrm{O}$ values (e.g., Sharp 2007), but interaction with a rock with a positive $\delta^{18} \mathrm{O}$ (SMOW) value would result in isotopic enrichment of the fluid. The host basalt belongs to the early Carboniferous Clyde Plateau Volcanic Formation which would have been overlain by later Carboniferous sedimentary rocks, including several marine limestones (British-Geological-Survey 1987; Glennie 2002), which would have positive $\delta^{18} \mathrm{O}$ values (e.g., Sharp 2007). A degree of interaction between negative $\delta^{18} \mathrm{O}$ meteoric water and the positive $\delta^{18} \mathrm{O}$ rocks it percolated down through to eventually precipitate the calcite vein would have resulted in the $\delta^{18} \mathrm{O}$ values of ca. $1 \%$ recorded from the clumped isotopes for the source fluid.

\section{Mull}

$\delta^{13} \mathrm{C}, \delta^{18} \mathrm{O}$, and $\Delta_{47}$ values are homogeneous at the centre and edge of the vein in sample MU04 from Mull. While the absolute age could not be measured due to low radiogenic $\mathrm{Pb}$ contents, the homogeneity of the isotopic values suggests precipitation in a single event. This is interpreted to have been synchronous with the emplacement of the Mull Central Complex (Walker 1970) at $58.48 \pm 0.18 \mathrm{Ma}$ (Chambers and Pringle 2001). Walker (1970) suggests a hydrothermal reservoir within the ca. $5 \mathrm{~km}$-wide metamorphic aureole of the Mull Central Complex, but does not identify a source of fluid within that zone. There may have been a component of juvenile magmatic water in the aureole but the clumped-isotope analysis of the calcite veins from Tobermory (ca. $10 \mathrm{~km}$ away from the aureole) record an isotopically depleted fluid $\delta^{18} \mathrm{O}$ of ca. $-10 \%$, suggesting that this is unlikely. A highly depleted fluid such as glacial water typically has $\delta^{18} \mathrm{O}$ values of $<-25 \%$ (e.g., Dansgaard 1954; Johnsen et al. 1972) if this were to undergo significant fluid-rock interaction with a basalt with a positive $\delta^{18} \mathrm{O}$ that could result in the calculated $\delta^{18} \mathrm{O}$ values of ca. $-10 \%$ for the Mull samples. However, there is no record of glaciation in the Palaeogene in Scotland and the active volcanism along the west of Scotland at this time would render this scenario unlikely (Murray 1992). A meteoric (precipitation) water source is deemed most likely for this sample. In the Palaeogene, Scotland was at a similar latitude to today, and therefore, precipitation $\delta^{18} \mathrm{O}$ values would be expected to be similar to today's based on the latitude effect in $\delta^{18} \mathrm{O}$ (e.g., Sharp 2007). Soulsby et al. (2000) measured average precipitation $\delta^{18} \mathrm{O}$ values of ca. $-7.7 \%$ in the present-day Cairngorms (a similar latitude to Mull), although there was extreme seasonal variation, as would be expected from ca. $-2 \%$ in the summer to ca. $-20 \%$ in the winter. In stream waters in the catchment analysed, $\delta^{18} \mathrm{O}$ values clustered around -8 to $-10 \%$ (Soulsby, et al., 2000). This is within the range of the calculated source fluid $\delta^{18} \mathrm{O}$ values from the Mull calcite vein sample. However, there is clear petrographic evidence of water-rock interaction the sample [presence of saponite replacing pyroxene/olivine (Fig. 6)] which would result in an isotopic enrichment; the initial precipitation would need to be isotopically lighter than the calculated $-10 \%$ values from the sample. This could be due to the presence of winter-only precipitation percolating down through the rocks to form the veins, although the hydrothermal system would be expected to be active over much longer timescales (e.g., Cathles et al. 1997; Chiaradia et al. 2013; Früh-Green et al. 2003; Henry et al. 1997). A high altitude setting is a more likely cause of a highly isotopically depleted precipitation which was the ultimate fluid source for the vein, as the isotopic composition of water becomes lighter at altitude due to cooler temperatures (e.g., Field 2010; Sharp 2007). The Mull Plateau Lava Formation is interpreted to be ca. $2 \mathrm{~km}$ thick (Walker 1970; Williamson and Bell 1994) and this may have given rise to a high altitude landscape on which isotopically depleted precipitation fell. This meteoric water would have percolated down through the lava pile, undergoing some limited water-rock interaction resulting in an isotopic enrichment from its value on precipitation, to the calculated ca. $-10 \%$ value calculated from the calcite vein.

\section{Conclusions}

Precipitation temperatures reconstructed from clumpedisotope analysis undergo closed-system bond reordering at temperatures of $>\mathrm{ca} .100{ }^{\circ} \mathrm{C}$. This paper showed that 
LA-ICP-MS U-Pb dating of hydrothermal calcite veins enables more robust interpretation of thermal history reordering models using samples from Arran and Loanhead in Scotland. In the Isle of Mull sample, where a U-Pb date could not be obtained, bond reordering models had to be run for a range of thermal histories, as the calcite precipitation age was not known. This meant that bond reordering could not be eliminated as conclusively as in the Arran and Loanhead samples, where a precipitation age from the LA-ICP-MS $\mathrm{U}-\mathrm{Pb}$ dating led to more certainty in the thermal history reordering models. This highlights the importance of coupling clumped-isotope thermometry and LA-ICP-MS U-Pb calcite dating in determining the temperature of hydrothermal fluids recorded in calcite veins. This paired approach is shown to be a robust approach to constrain the timing and precipitation temperature of calcite formation, and thus for tracking hydrothermal processes.

Acknowledgements This research was funded by Research Incentive Grant 70316 from the Carnegie Trust for the Universities of Scotland to JMM. Handling editor Joechen Hoefs together with 3 anonymous reviewers helped significantly improve this manuscript.

Open Access This article is distributed under the terms of the Creative Commons Attribution 4.0 International License (http://creativeco mmons.org/licenses/by/4.0/), which permits unrestricted use, distribution, and reproduction in any medium, provided you give appropriate credit to the original author(s) and the source, provide a link to the Creative Commons license, and indicate if changes were made.

\section{References}

Barker SLL, Cox SF, Eggins SM, Gagan MK (2006) Microchemical evidence for episodic growth of antitaxial veins during fracturecontrolled fluid flow. Earth Planet Sci Lett 250(1):331-344

Bernasconi SM, Müller IA, Bergmann KD, Breitenbach SFM, Fernandez A, Hodell DA, Jaggi M, Meckler AN, Millan I, Ziegler M (2018) Reducing uncertainties in carbonate clumped isotope analysis through consistent carbonate-based standardization. Geochem Geophys Geosyst 19(9):2895-2914

Brand WA, Assonov SS, Coplen TB (2010) Correction for the O-17 interference in delta(C-13) measurements when analyzing $\mathrm{CO}_{2}$ with stable isotope mass spectrometry (IUPAC Technical Report). Pure Appl Chem 82(8):1719-1733

British-Geological-Survey (1987) Arran Special Sheet S21 \& S13. British Geological Survey, Keyworth

Burisch M, Gerdes A, Walter BF, Neumann U, Fettel M, Markl G (2017) Methane and the origin of five-element veins: mineralogy, age, fluid inclusion chemistry and ore forming processes in the Odenwald, SW Germany. Ore Geol Rev 81:42-61

Burisch M, Walter BF, Gerdes A, Lanz M, Markl G (2018) Late-stage anhydrite-gypsum-siderite-dolomite-calcite assemblages record the transition from a deep to a shallow hydrothermal system in the Schwarzwald mining district, SW Germany. Geochim Cosmochim Acta 223:259-278

Cathles LM, Rerendi AHJ, Barrie T (1997) How long can a hydrothermal system be sustained by a single intrusive event? Econ Geol 92(7-8):766-771
Chambers LM, Pringle MS (2001) Age and duration of activity at the Isle of Mull Tertiary igneous centre, Scotland, and confirmation of the existence of subchrons during Anomaly 26r. Earth Planet Sci Lett 193(3-4):333-345

Chiaradia M, Schaltegger U, Spikings R, Wotzlaw J-F, Ovtcharova M (2013) How accurately can we date the duration of magmatichydrothermal events in porphyry systems?-An invited paper. Econ Geol 108(4):565-584

Cogne N, Doepke D, Chew D, Stuart FM, Mark C (2016) Measuring plume-related exhumation of the British Isles in Early Cenozoic times. Earth Planet Sci Lett 456:1-15

Coogan LA, Parrish RR, Roberts NMW (2016) Early hydrothermal carbon uptake by the upper oceanic crust: insight from in situ U-Pb dating. Geology 44(2):147-150

Cox SF, Munroe SM (2016) Breccia formation by particle fluidization in fault zones: implications for transitory, rupture-controlled fluid flow regimes in hydrothermal systems. Am J Sci 316(3):241-278

Craig H, Gordon LI, Horibe Y (1963) Isotopic exchange effects in evaporation of water. 1. Low-temperature experimental results. J Geophys Res 68(17):5079

Dansgaard W (1954) The O-18-Abundance in Fresh Water. Geochim Cosmochim Acta 6(5-6):241-260

Davies AJ, John CM (2017) Reducing contamination parameters for clumped isotope analysis: the effect of lowering Porapak ${ }^{\mathrm{TM}} \mathrm{Q}$ trap temperature to below $-50{ }^{\circ} \mathrm{C}$. Rapid Commun Mass Spectrom $31: 1313-1323$

Davies AJ, John CM (2019) The clumped (13C-18O) isotope composition of echinoid calcite: further evidence for "vital effects" in the clumped isotope proxy. Geochim Cosmochim Acta 245:172-189

Defliese WF, Hren MT, Lohmann KC (2015) Compositional and temperature effects of phosphoric acid fractionation on Delta(47) analysis and implications for discrepant calibrations. Chem Geol 396:51-60

Dennis KJ, Affek HP, Passey BH, Schrag DP, Eiler JM (2011) Defining an absolute reference frame for 'clumped' isotope studies of $\mathrm{CO}_{2}$. Geochim Cosmochim Acta 75(22):7117-7131

Des Marais DJ (2001) Isotopic evolution of the biogeochemical carbon cycle during the Precambrian. In: Valley JW, Cole DR (eds) Stable isotope geochemistry. Elsevier, Amsterdam, pp 555-578

Drake H, Heim C, Roberts NMW, Zack T, Tillberg M, Broman C, Ivarsson M, Whitehouse MJ, Àström ME (2017) Isotopic evidence for microbial production and consumption of methane in the upper continental crust throughout the Phanerozoic eon. Earth Planet Sci Lett 470:108-118

Eiler JM (2007) "Clumped-isotope" geochemistry-The study of naturally-occurring, multiply-substituted isotopologues. Earth Planet Sci Lett 262(3-4):309-327

Eiler JM (2011) Paleoclimate reconstruction using carbonate clumped isotope thermometry. Quatern Sci Rev 30(25-26):3575-3588

Emeleus CH, Bell BR (2005) The Palaeogene volcanic districts of Scotland. British Geological Survey, Nottingham

England RW (1988) The ascent and emplacement of granitic magma: the northern Arran granite, Durham University, $\mathrm{PhD}$ thesis

Field RD (2010) Observed and modeled controls on precipitation $\delta 180$ over Europe: from local temperature to the Northern Annular Mode. J Geophys Res Atmos 115:D12

Früh-Green GL, Kelley DS, Bernasconi SM, Karson JA, Ludwig KA, Butterfield DA, Boschi C, Proskurowski G (2003) 30,000 Years of Hydrothermal Activity at the Lost City Vent Field. Science 301(5632):495-498

Glennie KW (2002) Permian and Triassic. In: Trewin NH (ed) The geology of Scotland. The Geological Society, London, pp 301-321

Godeau N, Deschamps P, Guihou A, Leonide P, Tendil A, Gerdes A, Hamelin B, Girard JP (2018) U-Pb dating of calcite cement and 
diagenetic history in microporous carbonate reservoirs: case of the Urgonian Limestone, France. Geology 46(3):247-250

Goodfellow BW, Viola G, Bingen B, Nuriel P, Kylander-Clark ARC (2017) Palaeocene faulting in SE Sweden from U-Pb dating of slickenfibre calcite. Terra Nova 29(5):321-328

Gribble CD (1992) Loanhead quarry. In: Lawson JD, Weedon DS (eds) Geological excursions around glasgow and girvan. Geological Society of Glasgow, Glasgow, pp 235-239

Hansman RJ, Albert R, Gerdes A, Ring U (2018) Absolute ages of multiple generations of brittle structures by $\mathrm{U}-\mathrm{Pb}$ dating of calcite. Geology 46(3):207-210

Henkes GA, Passey BH, Wanamaker AD, Grossman EL, Ambrose WG, Carroll ML (2013) Carbonate clumped isotope compositions of modern marine mollusk and brachiopod shells. Geochim Cosmochim Acta 106:307-325

Henkes GA, Passey BH, Grossman EL, Shenton BJ, Perez-Huerta A, Yancey TE (2014) Temperature limits for preservation of primary calcite clumped isotope paleotemperatures. Geochim Cosmochim Acta 139:362-382

Henry CD, Elson HB, McIntosh WC, Heizler MT, Castor SB (1997) Brief duration of hydrothermal activity at Round Mountain, Nevada, determined from $\mathrm{Ar} 40 / \mathrm{Ar} 39$ geochronology. Econ Geol 92(7-8):807-826

Hill CA, Polyak VJ, Asmerom Y, Provencio P (2016) Constraints on a Late Cretaceous uplift, denudation, and incision of the Grand Canyon region, southwestern Colorado Plateau, USA, from U-Pb dating of lacustrine limestone. Tectonics 35(4):896-906

Horstwood MSA, Košler J, Gehrels G, Jackson SE, McLean NM, Paton C, Pearson NJ, Sircombe K, Sylvester P, Vermeesch P, Bowring JF, Condon DJ, Schoene B (2016) Community-derived standards for LA-ICP-MS U-(Th-) Pb geochronology-uncertainty propagation, age interpretation and data reporting. Geostand Geoanal Res 40(3):311-332

Huntington KW, Eiler JM, Affek HP, Guo W, Bonifacie M, Yeung LY, Thiagarajan N, Passey B, Tripati A, Daeron M, Came R (2009) Methods and limitations of 'clumped' $\mathrm{CO}_{2}$ isotope (Delta47) analysis by gas-source isotope ratio mass spectrometry. J Mass Spectrom 44(9): 1318-1329

John CM, Bowen D (2016) Community software for challenging isotope analysis: first applications of 'Easotope' to clumped isotopes. Rapid Commun Mass Spectrom 30(21):2285-2300

Johnsen SJ, Clausen HB, Dansgaard W, Langway CC (1972) Oxygen Isotope Profiles through Antarctic and Greenland Ice Sheets. Nature 235(5339):429-434

Kim ST, ONeil JR (1997) Equilibrium and nonequilibrium oxygen isotope effects in synthetic carbonates. Geochim Cosmochim Acta 61(16):3461-3475

Kluge T, John CM, Jourdan AL, Davis S, Crawshaw J (2015) Laboratory calibration of the calcium carbonate clumped isotope thermometer in the 25-250 degrees $\mathrm{C}$ temperature range. Geochim Cosmochim Acta 157:213-227

Knauth LP, Beeunas MA (1986) Isotope geochemistry of fluid inclusions in Permian halite with implications for the isotopic history of ocean water and the origin of saline formation waters. Geochim Cosmochim Acta 50(3):419-433

Lawson M, Shenton BJ, Stolper DA, Eiler JM, Rasbury ET, Becker TP, Phillips-Lander C, Buono AS, Becker SP, Pottorf R, Gray GG, Yurewicz D, Gournay J (2017) Deciphering the diagenetic history of the El Abra Formation of eastern Mexico using reordered clumped isotope temperatures and U-Pb dating. GSA Bull 130(3-4):617-629

Li Q, Parrish RR, Horstwood MSA, McArthur JM (2014) U-Pb dating of cements in Mesozoic ammonites. Chem Geol 376:76-83

Lu Y-C, Song S-R, Wang P-L, Wu C-C, Mii H-S, MacDonald J, Shen C-C, John CM (2017) Magmatic-like fluid source of the Chingshui geothermal field, NE Taiwan evidenced by carbonate clumped-isotope paleothermometry. J Asian Earth Sci 149:124-133

Ludwig KR (2012) User's manual for isoplot 3.75-4.15, Berkeley Geochronology Center

Mangenot X, Gasparrini M, Gerdes A, Bonifacie M, Rouchon V (2018) An emerging thermochronometer for carbonate-bearing rocks: delta(47)/(U-Pb). Geology 46(12):1067-1070

Meckler AN, Ziegler M, Millan MI, Breitenbach SF, Bernasconi SM (2014) Long-term performance of the Kiel carbonate device with a new correction scheme for clumped isotope measurements. Rapid Commun Mass Spectrom 28(15):1705-1715

Methner K, Mulch A, Fiebig J, Wacker U, Gerdes A, Graham SA, Chamberlain CP (2016) Rapid Middle Eocene temperature change in western North America. Earth Planet Sci Lett 450:132-139

Monaghan AA, Parrish RR (2006) Geochronology of carboniferousPermian magmatism in the Midland Valley of Scotland: implications for regional tectonomagmatic evolution and the numerical time scale. J Geol Soc 163:15-28

Monaghan AA, Pringle MS (2004) ${ }^{40} \mathrm{Ar} /{ }^{39} \mathrm{Ar}$ geochronology of Carboniferous-Permian volcanism in the Midland Valley, Scotland. Geol Soc Lond Spec Publ 223(1):219-241

Murray JW (1992) Palaeogene and Neogene. In: Cope JCW, Ingham JK, Rawson PF (eds) Atlas of palaeogeography and lithofacies. The Geological Society, London, pp 141-147

Nuriel P, Weinberger R, Kylander-Clark ARC, Hacker BR, Craddock JP (2017) The onset of the Dead Sea transform based on calcite age-strain analyses. Geology 45(7):587-590

Oliver NHS, Bons PD (2001) Mechanisms of fluid flow and fluid-rock interaction in fossil metamorphic hydrothermal systems inferred from vein-wallrock patterns, geometry and microstructure. Geofluids 1(2):137-162

Pagel M, Bonifacie M, Schneider DA, Gautheron C, Brigaud B Calmels D, Cros A, Saint-Bezar B, Landrein P, Sutcliffe C, Davis D, Chaduteau C (2018) Improving paleohydrological and diagenetic reconstructions in calcite veins and breccia of a sedimentary basin by combining Delta(47) temperature, delta O-18(water) and $\mathrm{U}-\mathrm{Pb}$ age. Chem Geol 481:1-17

Parrish RR, Parrish CM, Lasalle S (2018) Vein calcite dating reveals Pyrenean orogen as cause of Paleogene deformation in southern England. J Geol Soc 175:425-442

Passey BH, Henkes GA (2012) Carbonate clumped isotope bond reordering and geospeedometry. Earth Planet Sci Lett 351-352:223-236

Pickering R, Kramers JD, Partridge T, Kodolanyi J, Pettke T (2010) $\mathrm{U}-\mathrm{Pb}$ dating of calcite-aragonite layers in speleothems from hominin sites in South Africa by MC-ICP-MS. Quat Geochronol 5(5):544-558

Pisapia C, Deschamps P, Battani A, Buschaert S, Guihou A, Hamelin $\mathrm{B}$, Brulhet J (2018) U/Pb dating of geodic calcite: new insights on Western Europe major tectonic events and associated diagenetic fluids. J Geol Soc 175(1):60-70

Rasbury ET, Cole JM (2009) Directly dating geologic eveNTS: U-Pb dating of carbonates. Rev Geophys 47:3

Read WA, Browne MAE, Stephenson D, Upton BGJ (2002) Carboniferous. In: Trewin NH (ed) The geology of Scotland. The Geological Society of London, London, pp 251-299

Ring U, Gerdes A (2016) Kinematics of the Alpenrhein-Bodensee graben system in the Central Alps: oligocene/Miocene transtension due to formation of the Western Alps arc. Tectonics 35(6): 1367-1391

Roberts NMW, Walker RJ (2016) U-Pb geochronology of calcite-mineralized faults: absolute timing of rift-related fault events on the northeast Atlantic margin. Geology 44(7):531-534

Roberts NMW, Rasbury ET, Parrish RR, Smith CJ, Horstwood MSA, Condon DJ (2017) A calcite reference material for 
LA-ICP-MS U-Pb geochronology. Geochem Geophys Geosyst 18(7):2807-2814

Rollinson H (1993) Using geochemical data: evaluation, presentation, interpretation. Pearson Prentice Hall, Harlow

Schauble EA, Ghosh P, Eiler JM (2006) Preferential formation of 13C$18 \mathrm{O}$ bonds in carbonate minerals, estimated using first-principles lattice dynamics. Geochim Cosmochim Acta 70(10):2510-2529

Sharp Z (2007) Principles of stable isotope geochemistry. Pearson Prentice Hall, New Jersey

Shenton BJ, Grossman EL, Passey BH, Henkes GA, Becker TP, Laya JC, Perez-Huerta A, Becker SP, Lawson M (2015) Clumped isotope thermometry in deeply buried sedimentary carbonates: The effects of bond reordering and recrystallisation. GSA Bull 127:1036-1051

Soulsby C, Malcolm R, Helliwell R, Ferrier RC, Jenkins A (2000) Isotope hydrology of the Allt a' Mharcaidh catchment, Cairngorms, Scotland: implications for hydrological pathways and residence times. Hydrol Process 14(4):747-762

Stevenson CTE, Grove C (2014) Laccolithic emplacement of the Northern Arran Granite, Scotland, based on magnetic fabric data. In: Advances in volcanology, pp 1-25, Springer, Berlin, Heidelberg

Stolper DA, Eiler JM (2015) The kinetics of solid-state isotopeexchange reactions for clumped isotopes: a study of inorganic calcites and apatites from natural and experimental samples. Am J Sci 315(5):363-411

Swart PK (2015) The geochemistry of carbonate diagenesis: the past, present and future. Sedimentology 62(5):1233-1304

Walker GPL (1970) The distribution of amygdale minerals in mull and morvern (Western Scotland). In: Murty TVVGRK, Rao SS (eds)
Studies in earth sciences, west commemoration volume. Today and Tomorrow's Printers and Publishers, Faridabad, pp 181-194

Walter BF, Gerdes A, Kleinhanns IC, Dunkl I, von Eynatten H, Kreissl S, Markl G (2018) The connection between hydrothermal fluids, mineralization, tectonics and magmatism in a continental rift setting: fluorite $\mathrm{Sm}-\mathrm{Nd}$ and hematite and carbonates $\mathrm{U}-\mathrm{Pb}$ geochronology from the Rhinegraben in SW Germany. Geochim Cosmochim Acta 240:11-42

Warrington D, Ivimey-Cook HC (1992) Triassic. In: Cope JCW, Ingham JK, Rawson PF (eds) Atlas of palaeogeography and lithofacies. Memoir. Geological Society of London, London, pp 97-106

Williamson IT, Bell BR (1994) The Palaeocene lava field of west-central Skye, Scotland: stratigraphy, palaeogeography and structure. Trans R Soc Edinburgh Earth Sci 85:39-75

Woodcock N, Underhill J (1987) Emplacement-related fault patterns around the Northern Granite, Arran, Scotland. GSA Bull 98(5):515-527

Woodhead J, Pickering R (2012) Beyond $500 \mathrm{ka}$ : progress and prospects in the U-Pb chronology of speleothems, and their application to studies in palaeoclimate, human evolution, biodiversity and tectonics. Chem Geol 322:290-299

Woodhead J, Hellstrom J, Maas R, Drysdale R, Zanchetta G, Devine $\mathrm{P}$, Taylor E (2006) U-Pb geochronology of speleothems by MCICPMS. Quat Geochronol 1(3):208-221

Publisher's Note Springer Nature remains neutral with regard to jurisdictional claims in published maps and institutional affiliations. 